\title{
İstismarcı Yönetici Algısının Kaytarma Üzerindeki Etkisinde Duygusal Tükenmenin Aracılık Rolü: Otel İşletmelerinde Bir İnceleme*
}

The Effect of Abusive Supervision on Workplace Loafing and the Mediator Role of Emotional Exhaustion in this Relationship: An Examination on Hotel Businesses

\section{Emre SEZici*, Ömer Zafer GÜVEN**}

*Yrd. Doç. Dr., Dumlupınar Üniversitesi, Kütahya Sosyal Bilimler Meslek Yüksekokulu, Yönetim ve Organizasyon Bölümü, Germiyan Yerleşkesi, P.K. 43000, Kütahya.

E-posta: emre.sezici@dpu.edu.tr

**Yrd. Doç. Dr., Dumlupınar Üniversitesi, Kütahya Sosyal Bilimler Meslek Yüksekokulu, Otel Lokanta ve İkram Hizmetleri Bölümü, Germiyan Yerleşkesi, P.K. 43000, Kütahya.

E-posta: omerzafer.guven@dpu.edu.tr

\section{MAKALE BILGILERI \\ Makale işlem bilgileri: \\ Gönderilme tarihi: 23 Temmuz 2016 \\ Birinci düzeltme: 30 Eylül 2016 \\ İkinci düzeltme: 2 Kasım 2016 \\ Kabul: 10 Kasım 2016 \\ Anahtar sözcükler: İstismarcı yöneti- \\ ci, Kaytarma, Duygusal tükenme, Otel işletmeleri.}

\section{ARTICLE INFO}

Article history:

Submitted: 23 July 2016

Resubmitted: 30 September 2016

Resubmitted: 2 November 2016

Accepted: 10 November 2016

Key words: Abusive supervision, Loafing, Emotional exhaustion, Hotel businesses.

\section{Öz}

Bu çalıșmada, istismarcı yönetici algısının, kaytarma üzerindeki doğrudan etkisi ve duygusal tükenmenin, istismarcı yönetici algısı ile kaytarma ilișkisi üzerindeki aracı etkisi incelenmiștir. Bu kapsamda, Antalya iline bağlı Side-Manavgat ve Alanya bölgesinde faaliyet gösteren 13 otel işletmesinin (dört adet beş yıldızlı, yedi adet dört yıldızlı ve iki adet üç yıldızlı) ön büro, kat hizmetleri ve yiyecek içecek departmanlarında çalışan 269 katılımcıdan elde edilen veriler analize dâhil edilmiștir. Kolayda örnekleme yönteminin tercih edildiği çalıșmada verilerin analizinde, SPSS 16 ve Lisrel 8.51 paket programlarından yararlanılmıștır. Calıșma sonucunda duygusal tükenmenin, istismarcı yönetici algısı ile kaytarma ilişkisinde kısmi aracı bir rolünün olduğu ortaya çıkmıştır.

\section{GíRiş}

Her geçen gün iş örgütlerinde yıkıcı olarak nitelendirilen kimi davranışlar üzerine odaklanılarak yapılan araştırmaların artmakta olan sayısı, aslında bir yönüyle yönetici ile çalışan arasındaki ilişkinin önemini vurgularken; diğer yönüyle

* Bu çalışma, 29-31 Mayıs 2016 tarihleri arasında düzenlenen 24. Ulusal Yönetim ve Organizasyon Kongresi'nde sözlü bildiri olarak sunulmuş olan metnin, büyük ölçüde genişletilmesiyle üretilmiştir. de istismarcı yönetici davranışlarının çalışanın alg1 ve tutumları üzerindeki etkisini gözler önüne sermeye çalışmaktadır (Tepper 2000; Harvey vd. 2007; Ülbeği vd. 2013; Özdevecioğlu vd. 2014; Üçok ve Turgut 2014; Sakal ve Yıldız 2015). Aslında pasif ya da şiddet içermeyen işyeri saldırganlığını konu alan ilk çalışmalar (Tepper 2000) bu fenomenin az tekrarlı ve düşük görülme sıklığına sahip olduğunu belirtmiş olsalar da; bu durumun, günümüze kadar yapılan araştırmalarla 
hiçte başlangıçta düşünüldügü gibi olmadığı, gün geçtikçe görülme sıklığının düzenli olarak arttığ1 rapor edilmiştir (Burton ve Hoobler 2006; Harvey vd. 2007).

İstismarcı yönetici davranışları astın özyeterliğini (Duffy vd. 2002), özsaygisını (Hobman, vd. 2009) ve özgüvenini (Harvey vd. 2007) azaltmakta, acziyet (Ashforth 1994), üzüntü, anksiyete yaşama ve depresyona girme (Tepper 2000; Hobman vd., 2009) riskini arttırmaktadır. Özellikle yönetici ile ast arasında yaşanan kişisel çatışmalara bağlı olarak ortaya çıkan istismarcı yönetici davranışının, duygusal tükenmeyi (Tepper 2000; Yagil 2006; Grandey vd. 2007; Tepper vd. 2007; Harvey vd. 2007 ve $\mathrm{Wu}$ ve $\mathrm{Hu}, 2009$ ) ve kaytarmayı (Hmieleski ve Ensley 2007; Wei ve Si 2009; Kacmar vd. 2013) olumlu yönde yordadığı saptanmıştır. Aynı zamanda duygusal tükenme ile kaytarma davranışı arasındaki ilişkiyi konu alan önceki çalışmalara ilişkin bulgular (Wagner 1995; Bolton vd. 2012; Yeh 2015) alanyazında yer almaktadir.

Yerli ve yabancı alanyazında; istismarcı yönetici ve bu yönetim biçiminin iş örgütlerinde neden olduğu olumsuz sonuçları yukarıda ifade edilen değişkenlerin (duygusal tükenme ve kaytarma) tümünü bünyesinde toplayan herhangi bir çalışmaya rastlanmamıştır. Yapılan araştırmanın bu alanda Türkiye'de var olan boşluğun doldurulmasında istismarcı yönetici algısının bireysel iş sonuçlarını (duygusal tükenme ve kaytarma) ortaya koyması bakımından, gerek bilim sahasına gerekse ilgili sektöre bir katkı sağlayacağı düşünülmektedir.

\section{ALANYAZIN TARAMASI}

\section{Duygusal Olaylar Kuramı}

Weiss ve Cropanzano (1996) tarafından geliştirilen "Duygusal Olaylar Kuramı", iş örgütlerinde çalışanların duygu ve ruh hallerinin onların davranışları üzerindeki etkilerini açıklamaya çalışmaktadır (Şekil 1). Duygusal Olaylar Kuramına göre iş tatmini, bireyin işine yönelik algısını ifade etmektedir ve tecrübe edinilen duygusal olaylar bireyin işine yönelik sahip olduğu bu algıyı değiştirebilmektedir.

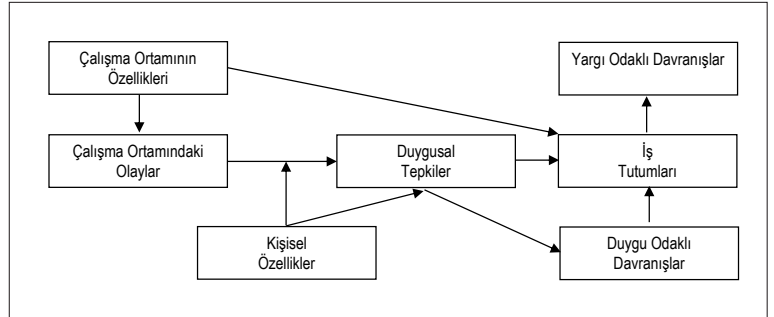

Şekil 1. Duygusal Olaylar Kuramının Makro Yapısı

Kaynak: Weiss ve Cropanzano (1996: 12).

Bu kuram, iş ortamında tecrübe edinilen farklı özelliklere sahip olayların (olumlu ya da olumsuz) oluşturduğu duyguların temel bileşenleri, sebepleri ve sonuçları üzerinden kuramsal bir çerçeve oluşturmaya çalışmaktadır. Bu sayede iş ile ilgili bilişsel değerlendirmelerle işe yönelik duygusal tepkiler arasındaki ayrıma dikkat çekmektedir (Miner ve Hulin 2000: 2).

Sonuç itibariyle çalışanların iş örgütlerinde sergilemiş oldukları davranışların ve tutumların altında sadece kişilik ve örgütsel özelliklerin bulunduğunu söylemek doğru olmayacaktır. Bu kuram Şekil 1'de de görüldüğü üzere, çalışanların iş örgütlerinde sergilemiş oldukları davranışların ve tutumların bir diğer belirleyicisi olarak iş ortamında deneyimledikleri duygusal olayların da etkisinin olduğunu ileri sürmektedir (Weiss ve Cropanzano 1996: 12).

Bu kuramdan hareketle, astın deneyimlediği duygusal olayların kaynağı olarak istismarcı yönetici algısının, duygusal tükenmişlik ve kaytarma davranışını arttırdığı ve duygusal tükenmişliğin, istismarcı yönetici algısı ile kaytarma arasında aracı rol oynadığı ileri sürülmektedir.

\section{İstismarcı Yönetici}

İş yerinde saldırganlığın bir türevi olarak "istismarcı yönetici" kavramı; astın, yöneticisi tarafından fiziksel şiddet içermeyen fakat süreklilik arz edecek bir biçimde sözlü ve sözel olmayan düşmanca bir muameleye maruz kalma durumuna ilişkin öznel değerlendirmesi" (Tepper 2000: 178) şeklinde tanımlanmaktadır. Alanyazında bu tür davranışların nitelendirilmesi sadece "istismarc1 yönetici" kavramıyla yapılmamıştır. İstismarc1 yönetici kavramının içeriğine karşılık gelen ya da içeriğiyle ilintili davranışların nitelendirilme- 
sinde kullanılan ve geniş çeşitliliğe sahip birçok kavram bulunmaktadır. Örneğin; "psikolojik yıldirma" (mobbing) (Zapf vd. 1996), "baltalayıcı yönetici" (supervisor undermining) (Duffy vd. 2002), "adi zorbalık" (petty tyranny) (Ashforth 1994), işyeri zorbalığ 1 (workplace bullying) (Hoel ve Cooper 2001) gibi nitelendirici kavramların varlığı, haliyle alanyazında üzerinde fikir birliğine varılmış "astlarına kötü muamelede bulunan yönetici" tanımının yapılmasının önüne geçmektedir. Ancak bu doğrultuda gerçekleştirilen çalışmalar incelendiğinde "istismarcı yönetici" (abusive supervision) (Tepper 2000; Harvey vd. 2007; Tepper vd. 2009; Ülbeği vd. 2013; Üçok ve Turgut 2014; Ülbeği vd. 2014; Sakal ve Yıldız 2015; Avunduk ve Yıldız 2016) kavramının daha önceki çalışmalarda daha fazla tercih edildiği görülmektedir.

İstismarcı yönetici algısı ile astın olumsuz iş sonuçları arasındaki ilişki incelendiğinde ise; "sapkın davranışlar" (Tepper, vd. 2009; Thau ve Mitchell 2010; Liu vd. 2010; Üçok ve Turgut 2014), "işten ayrılma eğilimi" (Harvey vd. 2007; Wayne vd. 2008), "üretkenlik karşıtı iş davranışları" (Robinson ve Bennett 1995); "iş stresi” (Yagil 2006; Harvey vd. 2007), “istenmeyen zorunlu düşünceler" (Thau ve Mitchell 2010), "astların işlevsel olmayan direnç gösterme eğilimleri" (Tepper vd. 2001), "tükenmişlik" (Tepper 2000; Yagil 2006; Grandey vd. 2007; Tepper vd. 2007; Harvey vd. 2007; Wu ve Hu 2009) düzeyleri artmaktadır.

Harvey vd. (2007: 266)'ne göre, istismarcı yönetici algısı ile duygusal tükenme arasındaki ilişkiyi konu alan çoğu çalışma, bu durumun yönetici ile ast arasında yaşanan kişisel çatışmadan kaynaklandığını vurgulamaktadır. Kişilerarası (ast-üst) çatışma neticesinde yaşanan duygusal tükenme, istismarcı yöneticinin devamlılık arz edecek şekilde astının özsaygı ve özyeterliğini hedef alan girişimlerine bağlı olarak ortaya çıkmaktadır. Daha önceki çalışmalarda duygusal tükenme ile istismarcı yönetici algısı arasında olumlu yönlü bir ilişkinin varlığ 1 tespit edilmiştir (Tepper 2000: 184; Harvey vd. 2007: 273). Bu noktada ast açısından yaşanan stresin kaynağı, öncelikle lider desteğinin kaybı olarak değerlendirilmelidir (Tepper 2000: 184).

\section{Duygusal Tükenme}

Hem bireysel hem de örgütsel pek çok faktörün kimi zaman öncülü ve kimi zamanda ardılı olan tükenmişlik, sonuçları itibari ile yönetilmesi gereken önemli bir fenomendir (Birdir ve Tepeci 2003: 95). Maslach ve Jackson'a (1981) göre tükenmişlik kişinin duygusal tükenme, duyarsızlaşma ve kişisel başarı hissinde azalma olmak üzere üç alt boyuta sahip psikolojik bir sendromdur. Duygusal tükenme, mesleki tükenmişliğin ve depresyonun anahtar bileşeni konumunda olup (Maslach ve Jackson 1981: 99) "bireysel stres boyutuna bağlı fiziksel ve duygusal yönden aşınmanın kronik bir hal alması" (Cropanzano vd. 2003: 160) olarak tanımlanmaktadır. Bu olgu, çalışanların kendilerini işlerine verememeleri ya da yardım isteyen kişilerin sorumluluklarını üstlenememeleri, engellenme ve gerginlik hissetmeleri, yorgunluk hissi, bedeni emareler, sinirlilik, depresyon ve aşırı alkol alımı ile karakterizedir. Sik rastlanan bir diğer emare, ertesi gün yeniden işe gitme korkusudur (Baysal 1995: 14). Dolay1sıyla psikosomatik şikâyetler nedeniyle işe devamsızlık ve işten ayrılma gibi hem çalışan hem de örgüt açısından olumsuz bir tablo ortaya çımaktadır.

\section{Kaytarma}

Kaytarma kavramı, bir ya da birden fazla grup üyesinin yapabilecekleri halde diğerlerinden daha az grup faaliyetlerine katkı yapmasına yönelik bir algıdır (Comer 1995: 648). Kaytarma, çal1şanın iş yerinde karşılaştı̆̆ 1 sorunlar karşısında bilinçli olarak çaba sarf etmemesi, geri çekilmesi, koşulları daha kötü hale getirecek sonuçları görmezden gelmesiyle ilgilidir. Bu durum psikolojik sözleşmenin tahribatı, iş doyumsuzluğu (Turnley ve Feldman 1999: 907), iş güvencesizliği, olumsuz yönetici tutumlarına ya da çalışma koşullarına (Davis-Blake vd. 2003: 486) bağlı olarak gelişen sorumsuzca davranışları ifade etmektedir.

Zayıf sorumluluk kişilik özelliklerine ya da iş ortamlarındaki olumsuzluklara bağlı olarak işinin resmi performans gereklerini ve iş tanımında belirlenmiş hususları zamanında ve olması gerektiği gibi yerine getirmeyen çalışanlar; işlerinden soğuyup devamsızlık yapmaya ve sanal 
kaytarma eğilimi göstermeye (Köse vd. 2012: 291), çalışma saatleri içinde işlerine odaklanmak yerine işle ilgisi olmayan konularla ilgilenmeye (Rusbult vd. 1988: 601) yatkındirlar. İstismarc1 yönetici algısı bir yönüyle çalışanların işe adanmışlıklarını ve motivasyonunu baltalamakta, işe yönelik genel tutumlarını olumsuz yönde etkilemektedir.

\section{YÖNTEM}

Araştırmanın yöntemi, süreç olarak aşağıdaki biçimde ele alınmıştır.

\section{Araştırmanın Amacı, Modeli ve Hipotezleri}

Çalışanlarda kaytarma girişimlerinin azaltılması ve bununla etkin mücadeleye yönelik tutum ve davranışların sergilenmesi ancak nedenlerinin doğru bir şekilde tespit edilmesiyle mümkündür. Bu kapsamda çalışmanın amacı, istismarcı yönetici algısının, kaytarma davranışının bir öncülü olduğu ve duygusal tükenmenin, istismarcı yönetici algısı ile kaytarma arasındaki ilişki üzerinde aracı bir etkisinin olabileceğinden hareketle otel işletmeleri çalışanlarında istismarcı yönetici algısı ile kaytarma ilişkisi ve bu ilişki üzerinde duygusal tükenmenin aracılık rolünü ampirik olarak belirlemektir (Şekil 2).

Alanyazın taramasında yer alan değişkenler ve bu değişkenler arasında önceden yapılan çalışmaların bulguları doğrultusunda çalışmanın hipotezleri aşağıdaki şekilde oluşturulmuştur:

$\mathrm{H}_{1}$ : İstismarcı yönetici algısı, duygusal tükenme üzerinde olumlu ve anlamlı bir etki yapmaktadır.

$\mathrm{H}_{2}$ : Duygusal tükenme, kaytarma üzerinde olumlu ve anlamlı bir etki yapmaktadır.

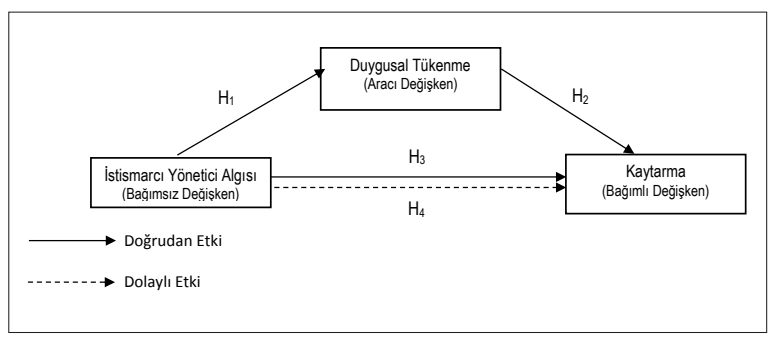

Şekil 2. Araştırma Modeli
$\mathrm{H}_{3}$ : İstismarcı yönetici algısı, kaytarma üzerinde olumlu ve anlamlı bir etki yapmaktadır.

$\mathrm{H}_{4}$ : İstismarcı yönetici algısı ile kaytarma arasındaki ilişkide duygusal tükenmenin aracılık rolü vardır.

\section{Evren ve Örneklem}

Antalya İl Kültür ve Turizm Müdürlüğü 2015 y111 verilerine göre araştırma kapsamındaki bölgelerde 429 adet belgeli otel işletmesi faaliyet göstermekte olup, bunlardan 58 adedi üç yıldız, 143 adedi dört yıldız ve 146 adedi ise beş yıldızlı otel işletmelerinden oluşmaktadır. Çalışmanın evrenini, zaman ve maddi yetersizliklerden dolayı Ağustos-Eylül 2015 tarihlerinde Antalya il sınırları içinde Side-Manavgat ve Alanya bölgesinde faaliyet gösteren 13 otel işletmesinin (dört adet beş yıldızlı, yedi adet dört yıldızlı ve iki adet üç yıldızlı) ön büro, kat hizmetleri ve yiyecek içecek departmanlarındaki çalışanlar oluşturmaktadır. Evrendeki işgören sayısını tespit etmek amacıyla araştırmanın yapıldığ 13 otel işletmesinin çalıştırdıkları işgören sayısına yönelik bilgiler ilgili otellerin İnsan Kaynakları departmanından elde edilmiş, bu otellerde yaklaşık 2100 işgören çalıştırıldığı, bu işgörenlerin yaklaşık 720 adedinin söz konusu departmanlarda görev yapan işgören olduğu, iş yoğunluğuna göre bu sayılarda değişiklikler olabileceği belirtilmiştir.

Araştırma kapsamına alınacak katılımcılar için hazırlanan 500 adet anketten, 287'sinin geri dönüşü olmuş, 18 anket analize uygun olmadığından dolayı değerlendirme dışı bırakılmış, geri kalan 269 anket ise değerlendirilmiştir, cevaplanma oranı yaklaşık \%54'tür.

\section{Ölçüm Araçları}

Tepper (2000: 189-190) tarafından geliştirilen ve Ülbeği vd. (2014: 5) tarafından Türkçe'ye uyarlanan "İstismarcı Yönetici Algısı Ölçeği" kullanılmıştır. Ölçek toplamda "Yöneticim geçmişteki hatalarımı yüzüme vurur", "Yöneticim işteki çabalarımı takdir etmez" gibi on beş maddeden oluşmakta ve her bir madde 1 ila 5 arası puanlanan (1: Kesinlikle Katılmiyorum, 5: Kesinlikle Katıllyorum) Likert ölçeği ile ölçülmüştür. Artan puanlar, istismarcı yönetici algısının yüksek olduğuna işaret etmektedir. 
Çalışmada Maslach ve Jackson (1981: 102) tarafından geliştirilen ve Ergin (1992: 143) tarafından Türkçe'ye uyarlanan Maslach Tükenmişlik Envanterinin ilk boyutu olan "Duygusal Tükenme Ölçeği" kullanılmıştır. Ölçek toplamda "İşimden soğuduğumu hissediyorum", "İş dönüşü kendimi ruhen tükenmiş hissediyorum" gibi dokuz madde ve her bir maddesi 1 ila 5 arası puanlanan (1: Kesinlikle Katılmiyorum, 5: Kesinlikle Katılıyorum) Likert ölçeği ile ölçülmüştür. Artan puanlar duygusal tükenmenin yüksek olduğuna işaret etmektedir.

Rusbult vd. (1988: 627) tarafından geliştirilen ve Türkçe'ye Yaşın (2013: 9) tarafından uyarlanan "İş Doyumsuzluğuna Verilen Tepkiler Ölçeği" nin Kaytarma ${ }^{1}$ boyutu kullanılmıştır. Ölçek toplamda "Yavaş çalışır ya da hatalar yaparım", "İşimin gereklerini tam yerine getirmem" gibi dört madde her bir madde 1 ila 5 arası puanlanan (1: Kesinlikle Katılmiyorum, 5: Kesinlikle Katılıyorum) Likert ölçeği ile ölçülmüştür. Kaytarma ölçeğinde artan puanlar, kaytarmanın yüksek olduğuna işaret etmektedir.

\section{Veri Toplama}

İstismarcı yönetici gibi hassas bir konuda araştırma yapılacağı için herhangi bir kurumda anket yapılmasının çok zorlu bir süreci gerektireceğinin düşünülmesinden dolayı örneklem seçiminde kolayda örnekleme yöntemi tercih edilmiştir. Bu bağlamda çalışmaya katılmaya gönüllü olan katılımclara, sektörde staj yapan öğrenciler aracılığıyla ulaşılmış ve veriler anket yöntemiyle müşteri ile yüz yüze iletişim kuran departmanlardaki işgörenlerden toplanmıştır. Ayrıca katılımcıların mevcut koşullar altında bağlı oldukları yönetici ile çalışma periyodunun altı aydan az olmamasına özen gösterilmiş ve altı aydan az bir süredir yöneticisi ile çalışmaya başladığını beyan eden katılımcıların anket formları araştırma kapsamına dâhil edilmemiştir. Bu sayede geri dönüşü sağlanan 287 anketten analize uygun olmad1ğ tespit edilen 18 anket çıkartılmış ve 269 anket analize tabi tutulmuştur.

\footnotetext{
${ }^{1}$ Alıntı yapılan çalışmada "Yokmuş Gibi Davranmak" başlı̆̆ altında isimlendirilen boyut, bu çalışmada "Kaytarma" olarak geçmektedir.
}

\section{Analiz ve Bulgular}

Araştırmada SPSS 16 ve Lisrel 8.51 paket programlarından yararlanilarak mevcut durumu analiz etmeye yönelik olarak yapılacak betimleyici analizin yanı sıra değişkenler arasındaki farklılıkları ve ilişkileri ortaya çıarabilmek için hipotez testleri kullanılmıştır. Ayrıca keşfedici ve doğrulayıcı faktör analizleriyle birlikte yapısal eşitlik modellemesi gerçekleştirilmiştir. Son olarak Sobel testi yapılmıştır.

\section{Örneklemin Kategorik Demografik Özellikleri}

Araştırma kapsamına alınan 269 katılımcının demografik özellikleri ise şu şekildedir: Katılımc1lar cinsiyetleri bakımından değerlendirildiğinde $\% 43,9^{\prime}$ u kadın, \%56,1'i erkeklerden oluşmaktadır. Toplam hizmet süresi açısından ise işgörenlerin \%27,1'i 6 ay-5 y1l, \%33,5'i 6-10 yıl, \%14,5'i 11-15 y1l, \%13,8'i 16-20 yıl ve \%11,2'si 21 yıl ve üzeri çalıştığı tespit edilmiştir. Yaş düzeyleri bakımından, \%27,9'u 20-29 yaş, \%38,3'ü 30-39 yaş, $\% 21,9^{\prime}$ u $40-49$ yaş ve $\% 11,9^{\prime}$ u 50 ve üstü yaş grubundadır. Katılımcıların eğitim düzeyleri açısından dağılımlarının ise İlkokul \%11,5; Lise \%43,5; Önlisans \%33,1 ve Lisans \%11,9 olduğu saptanmıştır. Katılımcılar çalıştıkları departman bakımindan değerlendirildiğinde; \%29,7'sinin Ön Büro, \%32,7'sinin Kat Hizmetleri ve \%37,5'inin ise Yiyecek İçecek departmanlarına bağlı olarak çalıştıkları tespit edilmiştir.

\section{Faktör Analizleri}

İstismarcı Yönetici Alg1sı Ölçeği, keşfedici faktör analiz sonuçlarına göre tek boyutludur. KaiserMayer-Orkin (KMO) değeri ,972 olarak bulunmuş ve Bartlett normal dağılım test sonucu anlamlı $(p<0,001)$ çıkmıştır. Ölçeğin açıklayabildiği toplam varyans, \%78,97'dir. Maddelerin faktör yükleri ,86 ile ,90 arasında değişmektedir. Ölçeğin faktör yapısının sağlamasını yapmak için yapılan doğrulayıcı faktör analizi sonucundan elde edilen değerler $(\Delta \chi 2 / \mathrm{sd}=2,65 ; \mathrm{GFI}=, 90 ; \mathrm{NFI}=, 96$; $\mathrm{CFI}=, 97$; RMSEA=,079; $\mathrm{RMR}=, 01)$ tek boyutlu yapıyı doğrulamaktadır.

Duygusal Tükenme Ölçeği, keşfedici faktör analiz sonuçlarına göre tek boyutludur. KaiserMayer-Orkin (KMO) değeri ,933 olarak bulun- 
muş ve Bartlett normal dağılım test sonucu anlamlı $(\mathrm{p}<0,001)$ çıkmıştır. Maddelerin faktör yükleri ,74 ile ,88 arasında değişmektedir. Ölçeğin açılayabildiği toplam varyans, \%68,13'tür. Ölçeğin faktör yapısının sağlamasını yapmak için yapılan doğrulayıcı faktör analizi sonucundan elde edilen değerler $(\Delta \chi 2 / \mathrm{sd}=1,58 ; \mathrm{GFI}=, 97 ; \mathrm{NFI}=, 99$; CFI=,99; RMSEA=,054; RMR=,042) tek boyutlu yapıyı doğrulamaktadır.

Kaytarma Ölçeği, keşfedici faktör analiz sonuçlarına göre tek boyutludur. Kaiser-MayerOrkin(KMO) değeri,739 olarak bulunmuş ve Bartlett normal dağılım test sonucu anlamlı $(p<0,001)$ çıkmıştır. Ölçeğin açılayabildiği toplam varyans, $\% 67,61$ 'dir. Maddelerin faktör yükleri ,78 ile ,87 arasında değişmektedir. Ölçeğin faktör yapısının sağlamasını yapmak için yapılan doğrulayıcı faktör analizi sonucundan elde edilen değerler $(\Delta \chi 2 / \mathrm{sd}=2,54 ; \mathrm{GFI}=, 91 ; \mathrm{NFI}=, 92$; CFI=,92; RMSEA $=, 080$; $\mathrm{RMR}=, 020$ ) tek boyutlu yapıyı doğrulamaktadır.

\section{Ortak Yöntem Varyansı Analizi}

Genellikle verinin tek bir kaynaktan toplanması ya da aynı anda farklı yapıları içeren ölçüm araçlarının aynı anda kullanılması, çeşitli yöntem ile ilgili sorunlara yol açmaktadır (Malhotra vd. 2006: 1865). Harman' in tek faktör testi, ortak yöntem varyansı sapmasının olup olmadığını test etmek için kullanılan yöntemlerden biridir ve çalışmada kullanılan ölçeklere yönelik faktör analizi yapıldığında tüm faktörlerin tek ve genel bir faktörde toplanmaması gerektiğini ileri sürmektedir. (Podsakoff vd. 2003: 889). Bu çerçevede üç değişken ile ilgili toplam 28 ifadeyle döngüsüz faktör analizi gerçekleştirildiğinde tüm faktörleri temsil eden tek ve genel bir faktörün açıkladığ 1 varyans $\% 41,66^{\prime}$ dır. Benzer şekilde faktör rotasyonlarının varimax yöntemi ile 90 derecelik rotasyonu sonucunda ortaya çıkan üç faktör, varyansın \%71,78'ini açıklamakta ve birinci faktörün açıklamış olduğu varyans miktarı \%38,72'dir. Elde edilen sonuçlar, çalışmada, ortak yöntem varyansı sorununun olmadığını göstermektedir.

\section{Güvenirlik ve Korelâsyon Analizleri}

Yapılan analizler sonucu değişkenlere ilişkin ortalamalar, standart sapma, güvenilirlik ve kore- lasyon değerleri, Tablo 1'de verilmektedir. Değiş̧kenlerin güvenirlik katsayıları faktörlerin iç tutarlıklarını sağladıklarını göstermektedir (Güriş ve Astar 2015: 283) ve İstismarcı Yönetici Alg1sı değişkeni için ,88; Duygusal Tükenme değişkeni için , 89 ve Kaytarma değişkeni için ,84 olup Cronbach Alpha ile hesaplanıp Tablo 1'de sunulmuştur. Değişkenler arası korelasyonlar incelendiğinde ise istismarcı yönetici alg1sı, duygusal tükenme ve kaytarma arasında doğru yönlü ve anlamlı ilişkiler olduğu görülmektedir.

\section{Ölçüm Modeline illişkin Doğrulayıcı Faktör Analizi}

Araştırma hipotezlerinin Yapısal Eşitlik Modeli kullanılarak test edilmesine geçmeden önce, doğrulayıcı faktör analizi kullanılarak ölçüm modeli oluşturulmuş ve değişkenler ile faktörler arasında bir uyum yani yüksek bir korelâsyon olup olmadığı araştırılmıştır. Kovaryans matrisi ve Maksimum Benzerlik Tahmini (MLE) kullanılarak yapılan doğrulayıcı faktör analizi sonucunda bulunan parametre tahmin değerlerinin olumlu, 0,50 ile 0,99 değerleri arasında olması ve ayrıca teorik değerlerinin üzerinde $t$ değerlerine sahip ve istatistiksel olarak anlamlı olması gerekmektedir. Doğrulayıcı faktör analiziyle ulaşılan değerler $\left(\Delta \chi^{2}=654,33 ; \mathrm{df}=336 ; \Delta \chi^{2}\right)$ $\mathrm{df}=1,95 ;$ RMSEA $=0,059 ; \mathrm{GFI}=, 85 ; \mathrm{IFI}=, 95 ; \mathrm{NFI}=, 92$; $\mathrm{NNFI}=$,95; $\mathrm{CFI}=$,95; RMR=,023) alanyazında genel kabul görmüş uyum istatistik referans değerleriyle (Şimşek 2007: 14) karşılaştırıldığında ele alınan kavramlara ilişkin uygun faktör yapısına ulaşıldığı görülmektedir.

\section{Yapısal Eşitlik Modellemesi ile Modelin Test Edilmesi}

Yukarıda bahsedilen doğrulayıcı faktör analizi ile modelin gerekli uyum değerleri sağlamasından sonra, araştırma hipotezlerinin Yapısal Eşit-

Tablo 1. Değişkenlere İlişkin Ortalama, Standart Sapma, Korelâsyon ve Güvenilirlik Değerleri

\begin{tabular}{lccccc}
\hline Değişkenler & Ort. & S.S. & 1 & 2 & 3 \\
\hline 1 İstismarcı Yönetici Algısı & 1,95 &, 56 & $(, 88)$ & & \\
\hline 2 Duygusal Tükenme & 2,90 &, 51 &, $193 * *$ & $(, 89)$ & \\
\hline 3 Kaytarma & 1,93 &, 46 &, $258 * *$ &, $497 * *$ & $(, 84)$ \\
\hline $\begin{array}{l}\text { N=269 * p }<, 05 \\
\text { Cronbach alfa güvenilirlik katsayısidır. }\end{array}$
\end{tabular}

Cilt 28 Sayı 1 - Bahar 2017 
lik Modeli kullanılarak test edilmesine geçilmiştir. Analiz için "Lisrel 8.51 for Windows" paket programı kullanılmış ve model parametrelerinin tahmininde, doğrulayıcı faktör analizinde kullanılan Maksimum Benzerlik Yöntemi (MLE) uygulanmıştır. Araştırma modelinde, istismarcı yönetici algısının, kaytarma üzerindeki doğrudan ve duygusal tükenme aracılığıyla etkisi araştırılacaktır. Aracılık etkisi Baron ve Kenny'nin (1986: 1176) ileri sürdüğü dört kıstasın sağlanmasına yönelik süreç temel alınarak gerçekleştirilecektir.

Öncelikle bağımsız değişken istismarcı yönetici algısının, aracı değişken duygusal tükenme üzerindeki etkiye bakılmış ve standart $\beta$ katsa$\mathrm{y} ı \mathrm{~s} 1,20$ olarak tespit edilmiştir. Ayrıca $\mathrm{p}<0,01$ $(\mathrm{R} 2=0,04)$ anlamlılık düzeyinde geçerli uyum değerlerine sahip olduğu $\left(\Delta \chi^{2} / \mathrm{df}=2,69 ; \mathrm{GFI}=, 89\right.$; $\mathrm{IFI}=$,92; NFI=,89; NNFI=,92; CFI=,92; RMR =,040) görüldükten ve H1 hipotezi desteklendikten sonra ikinci aşamaya geçilmiştir.

İkinci olarak aracı değişken duygusal tükenmenin, bağımlı değişken kaytarma üzerindeki etkisine bakılmış ve standart $\beta$ katsayısı ,60 ola- rak saptanmıştır. Ayrıca $p<0,01(\mathrm{R} 2=0,36)$ anlamlılık düzeyinde geçerli uyum değerlerine sahip olduğu $\left(\Delta \chi^{2} / \mathrm{df}=2,48 ; \mathrm{GFI}=, 89 ; \mathrm{IFI}=, 93 ; \mathrm{NFI}=, 88\right.$; $\mathrm{NNFI}=$,93; $\mathrm{CFI}=$,93; $\mathrm{RMR}=$,030) görüldükten ve H2 hipotezi desteklendikten sonra üçüncü aşamaya geçilmiştir.

Üçüncü basamakta ise bağımsız değişken istismarcı yönetici algısının, bağımlı değişken kaytarma üzerindeki etkisine bakılmış ve standart $\beta$ katsayısı ,38 olarak tespit edilmiştir. Ayrıca $\mathrm{p}<0,01(\mathrm{R} 2=0,14)$ anlamlılık düzeyinde geçerli uyum değerlerine sahip olduğu $\left(\Delta \chi^{2} / \mathrm{df}=2,69\right.$; $\mathrm{GFI}=, 89 ; \mathrm{IFI}=, 92 ; \mathrm{NFI}=, 89 ; \mathrm{NNFI}=, 92 ; \mathrm{CFI}=, 92$; $\mathrm{RMR}=, 040)$ görüldükten ve H3 hipotezi kabul edildikten sonra son aşamaya geçilmiştir.

Şekil 3'te görülen yollar üzerindeki değerler, standart $\beta$ katsayısıdır. Araştırma Modelinin, $\mathrm{p}<0,01(\mathrm{R} 2=0,41)$ anlamlılık düzeyinde geçerli uyum değerlerine sahip olduğu $\left(\chi^{2} / \mathrm{df}=2,49\right.$; $\mathrm{GFI}=$,90; IFI $=, 93 ; \mathrm{NFI}=, 89$; $\mathrm{NNFI}=, 93 ; \mathrm{CFI}=, 93$; $\mathrm{RMR}=$,025) görülmüş ve $\mathrm{H} 4$ hipotezi kabul edilmiştir.

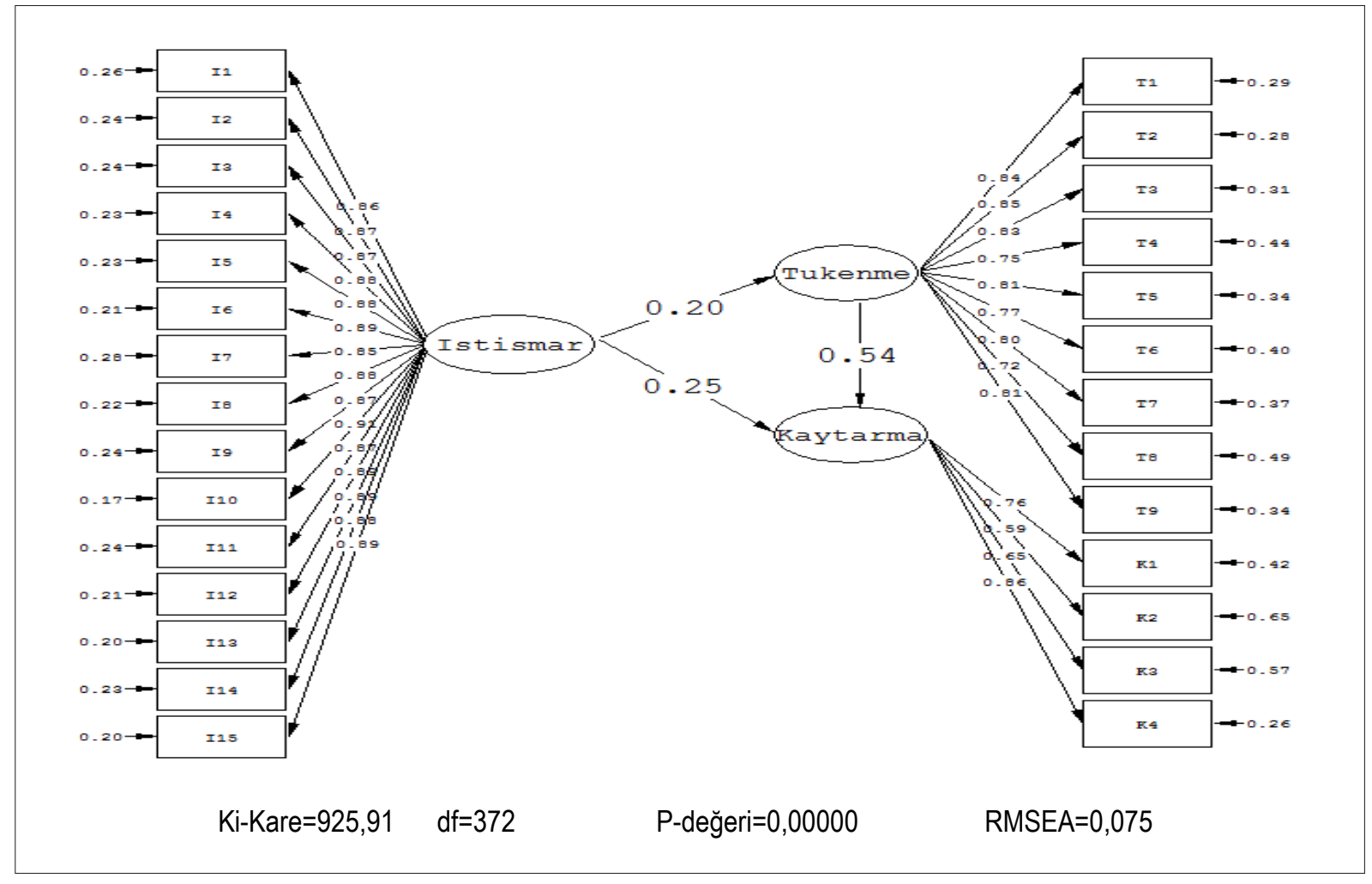

Şekil 3. Araştırma Modeli 
Birinci basamakta istismarcı yönetici algısının, duygusal tükenmeyi anlamlı bir şekilde olumlu yönde yordadığı görülmektedir. İkinci basamağın tahmin sonucu ise duygusal tükenmenin anlamlı bir biçimde kaytarmayı arttırdığını göstermektedir. Aracılık etkisinin testinin üçüncü basamağında ise istismarcı yönetici algısının, kaytarmayı arttırma eğiliminde olduğu görülmektedir. Tahmin edilen Şekil 3'te ise aracı değişkenin, açıklayıcı değişken olarak modele dâhil edilmesiyle birlikte üçüncü basamakta elde edilen katsayının $(0,38)$ azaldığ $1(0,25)$ görülmekte$\operatorname{dir}(p<0,01)$. Buna göre istismarcı yönetici alg1S1nın kaytarma üzerindeki etkisi, duygusal tükenme aracılığıyla da gerçekleşmektedir. Bu nedenle sonuçlar, kısmi aracılık etkisini ortaya koymaktadir.

Bir aracılık etkisinin bulunması durumunda bu etkinin istatistikî olarak anlamlı olup olmadığının doğrulanması Sobel (1982: 299) testi aracıl1ğıyla yapılmaktadır. Yapılan Sobel testine göre, duygusal tükenmenin aracılık etkisinin istatistikî olarak anlamlı olduğu doğrulanmıştır $(z=3,16$; Std.Hata $=0,032 ; \mathrm{p}<0,01$ ).

\section{SONUÇ}

Çalışmada Antalya il sınırları içinde Side-Manavgat ve Alanya bölgesinde faaliyet gösteren 13 otel işletmesinin (dört adet beş yıldızlı, yedi adet dört yıldızlı ve iki adet üç yıldızlı) ön büro, kat hizmetleri ve yiyecek içecek departmanlarındaki çalışanların istismarcı yönetici algıları ile kaytarma düzeyleri arasındaki regresyon ilişkisinde duygusal tükenmenin aracılık etkisi incelenmiştir.

İstismarcı yönetici algısının, duygusal tükenme üzerinde olumlu yönlü bir etki yaptığı saptanmıştır. Buna göre yönetici ile ast arasında yaşanan olumsuzluklar, çalışanın işe olan adanmışlığını sistematik olarak köreltmekte, özsaygı ve özyeterliğini baltalamakta dolayısıyla çalışanın kendini işe verememesine, gerginlik ve yorgunluk hissine bağlı olarak çeşitli psikolojik ve somatik semptomlarla karakterize olan duygusal tükenmeye neden olmaktadır. Elde edilen bu sonuç, yazındaki birçok çalışmanın bulgularıyla desteklenmektedir (Tepper 2000; Yagil 2006; Grandey vd. 2007; Tepper vd. 2007; Harvey vd. 2007; $\mathrm{Wu}$ ve $\mathrm{Hu} 2009$ ).
Duygusal tükenmenin, kaytarma üzerinde olumlu yönlü bir etki yaptığı saptanmıştır. Buna göre bireysel stres boyutuna dayalı olarak fiziksel ve duygusal yönden deneyimlenen aşınmanın kronik bir hal alması, beraberinde çalışanların işlerine kendilerini tam olarak ver(e)memelerine, özentisiz çalışmalarına, sorunların çözümü için aktif çaba göster(e)memelerine ve dolayısıyla var olan koşulların daha fazla kötüleşmesine neden olmaktadır. Elde edilen bu sonuç, yazındaki birçok çalışmanın bulgularıyla desteklenmektedir (Wagner 1995; Bolton vd. 2012; Yeh, 2015).

İstismarcı yönetici algısının, kaytarma davranışını arttırıcı yönlü bir etki yaptığı saptanmıştır. Buna göre istismarcı yöneticilerin, astlarla aktif iletişime girmemesi, astların kendi potansiyellerinin farkına varmaları yerine işlevsel olmayan kişisel çatışmalar üzerinden kendilerini tanımlamaları, örgüt içinde astların kendilerini güvende hissetmelerini sağlayan girişim(ler)de bulunmamaları, çalışanların iş tanımlarında açık bir şekilde tanımlanmış performans göstergelerini layıkıla yerine getir(e)memelerine neden olmaktadır. Elde edilen bu sonuç, yazındaki birçok çalışmanın bulgularıla desteklenmektedir (Hmieleski ve Ensley 2007; Wei ve Si 2009; Kacmar vd. 2013).

İstismarcı yönetici algısı ile kaytarma arasındaki ilişkide duygusal tükenmenin kısmi aracılık rolü saptanmıştır. Buna göre, çalışanların istismarcı yönetici algılarına bağlı olarak ortaya çıkan kaytarma davranışları sadece duygusal tükenme üzerinden gerçekleşmemektedir. Bir başka deyişle astın istismarcı yönetici algısına bağlı olarak kaytarma davranışını sergilemesi için duygusal yönden tükenme de yaşıyor olmasına gerek yoktur. Ancak astın istismarcı yönetici algısı ile birlikte yaşamakta olduğu duygusal tükenmenin varlığı, kaytarma davranışı nispeten daha fazla sergilemesine zemin oluşturmaktadır. Bu bulgu uygulama açısından istismarcı yönetici algısının, otel işletmeleri ve çalışanları üzerindeki sonuçlarının duygusal tükenme ile birlikte küçümsenmemesi gerektiğini tezini kuvvetlendirmektedir. Bu noktada ast açısından yaşanan kaytarma davranışının varlığı, öncelikle lider desteğinin kaybı, sonrasında da duygusal tükenmişliğin sonuçları 
olarak değerlendirilmelidir. Aynı zamanda yapılan analizler kuramsal açıdan otel işletmelerinde çalışanların iş örgütlerinde yaşamış oldukları olaylara bağlı olarak duygu ve ruh hallerinin bireyin işine yönelik algısının ve iş sonuçları üzerinde etkisinin olduğunu göstermektedir.

Çalışma, kesitsel bir araştırma olduğu ve kolayda örnekleme metodu kullanılarak yapıldığı için neden-sonuç çıkarımı ve bulgularının genellenebilirliği ile ilgili kısıtları mevcuttur.

\section{TEŞEKKÜR}

Verilerin toplanması sürecinde, araştırmaya katılım sağlayan tüm otel kurumlarına, yönetici ve çalışanlarına göstermiş oldukları ilgi ve anlayıştan dolayı teşekkür ediyoruz.

\section{KAYNAKÇA}

Ashforth, B. E. (1994). Petty Tyranny in Organizations, $H u$ man Relations, 47: 755-778.

Avunduk, Z. B. ve Yıldız, B. (2016). İstismarcı Yönetim Alg1Sı ile Örgütsel Bağlllık Arasındaki İlişkide Örgüt Temelli Özsaygının Moderator Etkisi. 15. Ulusal İşletmecilik Kongresi Bildiri Özet Kitapçı̆̆ (26 - 28 Mayıs 2016), İstanbul Üniversitesi, 15: 240-240.

Baron, R. ve Kenny, D. (1986). The Moderator-Mediator Variable Distinction in Social Psychological Research: Conceptual, Strategic, and Statistical Considerations, Journal of Personality and Social Psychology, 51 (6): 1173-1182.

Baysal, A. (1995). Lise ve Dengi Okul Öğretmenlerinde Meslekte Tükenmişliğe Etki Eden Faktörler, (Yayımlanmamış Doktora Tezi), Dokuz Eylül Üniversitesi Sosyal Bilimler Enstitüsü.

Birdir, K. ve M. Tepeci (2003). Otel Genel Müdürlerinde Tükenmişlik Sendromu ve Tükenmişliğin Genel Müdürlerin İşlerini Bırakma Tutumlarına Etkileri, Anatolia: Turizm Araştırmalan Dergisi, 14 (2): 93-106.

Bolton, L. R., Harvey, R. D., Grawitch, M. J. ve Barber, L. K. (2012). Counterproductive Work Behaviours in Response to Emotional Exhaustion: A Moderated Mediational Approach, Stress and Health, 28 (3): 222-233.

Burton, J. P. ve Hoobler, J.M. (2006). Subordinate Self-Esteem and Abusive Supervision, Journal of Managerial Issues, 18: 340-355.

Comer, D. R. (1995). A Model of Social Loafing in Real Work Groups, Human Relations, 48: 647-667.

Cropanzano, R., Rupp, D. E. ve Byrne, Z. S. (2003). The Relationship of Emotional Exhaustion to Work Attitudes, Job Performance, and Organizational Citizenship Behaviors, Journal of Applied Psychology, 88: 160-169.

Davis-Blake, A., Broschak, J. P. ve George, E. (2003), Happy Together? How Using Nonstandard Workers Affects Exit, Voice, and Loyalty among Standard Employees, Academy of Management Journal, 46 (4): 475-485.
Duffy, M. K., Ganster, D. C. ve Pagon, M. (2002). Social Undermining in the Workplace, Academy of Management Journal, 45 331-351.

Ergin, C. (1992). Doktor ve Hemşirelerde Tükenmişlik ve Maslach Tükenmişlik Ölçeğinin Uyarlanması, İçinde; Rüveyde Bayraktar ve İhsan Dağ (Editörler) VII. Ulusal Psikoloji Kongresi Bilimsel Çalışmaları (ss. 143-154), Hacettepe Üniversitesi, Ankara.

Grandey, A. A., Kern, J. ve Frone, M. (2007). Verbal Abuse from Outsiders Versus Insiders: Comparing Frequency, Impact on Emotional Exhaustion, and the Role of Emotional Labor, Journal of Occupational Health Psycho$\log y, 12: 63-79$.

Güriş, S. ve Astar, M. (2015). Bilimsel Araştırmalarda SPSS ile İstatistik. İkinci Baskı, İstanbul: Der Yayınları.

Harvey, P., Stoner, J., Hochwarter, W. ve Kacmar, C. (2007). Coping with Abusive Supervision: The Neutralizing Effects of Ingratiation and Positive Affect on Negative Employee Outcomes, The Leadership Quarterly, 18: 264280.

Hmieleski, K. M. ve Ensley, M. D. (2007). The Effects of Entrepreneur Abusive Supervision, Academy of Management Proceedings, 1: 1-6.

Hobman, E. V., Restubog, S. L. D., Bordia, P. ve Tang, R. L. (2009). Abusive Supervision in Advising Relationships: Investigating the Role of Social Support, Applied Psychology: An International Review, 58: 233-256.

Hoel, H. ve Cooper, C. L. (2001). Origins of Bullying: Theoretical Frameworks for Explaining Workplace Bullying, İçinde; N. Tehrani (Editör), Building a Culture of Respect: Managing Bullying at Work, Londra: Taylor \& Francis, 3-19.

Kacmar, K. M., Whitman, M. V. ve Harris, K. J. (2013). The Lingering Impact of Abusive Supervision, The Journal of Applied Management \& Entrepreneurship, 18 (3): 51-71.

Köse, S., Oral, L. ve Türesin, H. (2012). İş Yaşamında Sosyal Kolaylaştırma Kavramı ve Sanal Kaytarma ile İliş̧kisi: Araştırma Görevlileri Üzerinde Bir Araştırma, Sosyal ve Beşeri Bilimler Dergisi, 4 (1): 287-295.

Liu, J., H.K. Kwan, L. W. ve W. Wu (2010). Abusive Supervision and Subordinate Supervisor-directed Deviance: The Moderating Role of Traditional Values and The Mediating Role of Revenge Cognitions, Journal of Occupational and Organizational Psychology, 83: 835-856.

Malhotra, N.K., Kim, S.S. ve Patil, A. (2006). Common Method Variance in IS Research: A Comparison of Alternative Approaches and A Reanalysis of Past Research, Management Science, 52 (12): 1865-1883.

Maslach C. ve Jackson S. E. (1981). The Measurement of Experienced Burnout, Journal of Occupational Behaviour, 2: 99-113.

Miner, A. G. ve Hulin, C. L. (2000). Affect, Attitude, Behavior Links in Affective Events Theory, Second International Conference On Emotions in Organizational Life, Toronto, 10: 1-13.

Özdevecioğlu, M., Akın, M., Karaca, M. ve İştahlı, B. (2014). Kötü Niyetli Yönetim Algılamasının Çalışanların Performansları Üzerindeki Etkisinde Duygusal Zekânın Rolü, Çankırı Karatekin Üniversitesi İ̈BF Dergisi, 4 (1): 1-18. 
Podsakoff, P. M., Mackenzie, S. B., Podsakoff, N. P. ve Lee, J.-Y. (2003). Common Method Biases in Behavioral Research: A Critical Review of the Literature and Recommended Remedies, Journal of Applied Psychology, 88 (5): 879-903.

Robinson, S. L. ve Bennett, R. J. (1995). A Typology of Deviant Workplace Behaviors: A Multidimensional Scaling Study, Academy of Management Journal, 38: 555-572.

Rusbult, C. E., Farrel D., Rogers G. ve Mainous III A. G. (1988). Impact of Exchange Variables on Exit, Voice, Loyalty and Neglect: An Integrative Model of Responses to Declining Job Satisfaction, Academy of Management Journal, 31 (3): 599-627.

Sakal, Ö. ve Yıldız, S. (2015). İstismarcı Yönetim Alg1sı ile Örgütsel Sessizlik Arasındaki İlişkide Güç Mesafesi ve Örgütsel Tabanlı Benlik Saygısı Değiş̧kenlerinin Rolü, 3. Örgütsel Davranış Kongresi (6-7 Kasım 2015) Bildiriler Kitabı, Gaziosmanpaşa Üniversitesi, 389-395.

Sezici, E. (2016). İzleyicilerin Yıkıcı Liderlik Algısı ve Sonuçları, Dumlupinar Üniversitesi Sosyal Bilimler Dergisi, 47: 106-121.

Sobel, M. E. (1982). Asymptotic Confidence Intervals for Indirect Effects in Structural Equation Models, Sociological Methodology, 13: 290-312.

Şimşek, Ö. F. (2007). Yapısal Eşitlik Modellemesine Giriş Temel Ilkeler ve Lisrel Uygulamaları. Ankara: Ekinoks Yayınevi.

Tepper, B. J. (2000). Consequences of Abusive Supervision, Academy of Management Journal, 43 (2): 178-190.

Tepper, B. J. (2007). Abusive Supervision in Work Organizations: Review, Synthesis, and Research Agenda, Journal of Management, 33: 261-289.

Tepper, B. J., Carr, J. C., Breaux, D. M., Geider, S., Hu, C. ve Hua, W. (2009). Abusive Supervision, Intentions to Quit, and Employees' Workplace Deviance: A Power/Dependence Analysis, Organizational Behavior and Human Decision Processes, 109: 156-167.

Tepper, B. J., Duffy, M. K. ve Shaw, J. D. (2001). Personality Moderators of the Relationships between Abusive Supervision and Subordinates' Resistance, Journal of Applied Psychology, 86: 974-983.

Thau, S. ve Mitchell, M. S. (2010). Self-gain or Self-regulation Impairment? Tests of Competing Explanations of the Supervisor Abuse and Employee Deviance Relationship through Perceptions of Distributive Justice, Journal of Applied Psychology, 95: 1009-1031.

Turnley, W. H. ve Feldman, D. C. (1999). The Impact of Psychological Contract Violations on Exit, Voice, Loyalty and Neglect, Human Relations, 52 (7): 895-922.
Üçok, D. ve Turgut, T. (2014). İstismarcı Yönetici Davranış1nın İşyerindeki Sapkın Davranışlar Üzerindeki Rolü, Eskişehir Osmangazi Üniversitesi İ̈BF Dergisi, 9 (3): 163179.

Ülbeği, İ. D., Özgen, H. M. ve Özgen, H. (2013). Örgütsel Ortamda İstismarcı Yönetim ve İzlenim Yönetimi Üzerine Bir Araştırma, Çukurova Üniversitesi Sosyal Bilimler Enstitüsü Dergisi, 22 (2): 1-14.

Ülbeği, İ. D., Özgen, H. M. ve Özgen, H. (2014). Türkiye'de İstismarc1 Yönetim Ölçeğinin Uyarlaması: Güvenirlik ve Geçerlik Analizi, Çukurova Üniversitesi Sosyal Bilimler Enstitüsü Dergisi, 23 (1): 1-12.

Wagner, J. A. (1995). Studies of Individualism-Collectivism: Effects on Cooperation in Groups, Academy of Management Journal, 38 (1): 152-173.

Wayne, S. J., Hoobler, J. M., Marinova, S. ve Johnson, M. M. (2008). Abusive Behavior: Trickle-Down Effects Beyond the Dyad, Academy of Management Proceedings, 1-6.

Wei, F. ve Si, S. (2013). Tit for Tat? Abusive Supervision and Counterproductive Work Behaviors: The Moderating Effects of Locus of Control and Perceived Mobility, Asia Pacific Journal of Management, 30 (1): 281-296.

Weiss, H. M. ve R. Cropanzano (1996). Affective Events Theory: A Theoretical Discussion Of The Structure, Causes And Consequences Of Affective Experiences At Work, Research in Organizational Behavior, 18 (1): 1-79.

$\mathrm{Wu}, \mathrm{T}$. ve Hu, C. (2009). Abusive Supervision and Employee Emotional Exhaustion: Dispositional Antecedents and Boundaries, Group \& Organization Management, 34: 143169.

Yagil, D. (2006). The Relationship of Abusive and Supportive Workplace Supervision to Employee Burnout and Upward Influence Tactics, Journal of Emotional Abuse, 6: 49-65.

Yaşın, F. (2013). İş Doyumsuzluğuna Verilen Tepkiler Ölçeği: Geçerlilik ve Güvenilirlik Çalışması, Nesne, 1 (2): 1-20.

Yeh, C-W. (2015). Relationships among Social Loafing, Negative Mood, Emotional Exhaustion and Service Performance: Transformational Leadership as Moderators, Journal of Human Resource Management, 15 (1): 55-86.

Zapf, D., Knorz, C. ve Kulla, M. (1996). On the Relationship between Mobbing Factors, and Job Content, Social Work Environment, and Health Outcomes, European Journal of Work and Organizational Psychology, 5: 215-37. 

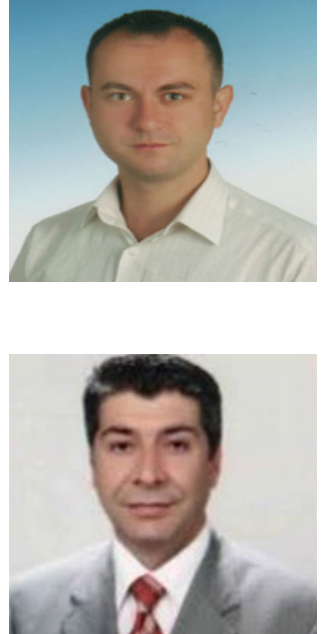

Emre SEZici

Dumlupınar Üniversitesi İktisadi ve İdari Bilimler Fakültesi İşletme Bölümünden mezun oldu (1999). Yüksek Lisans derecesini Dumlupınar Üniversitesi'nden Yönetim ve Organizasyon dalından (2001), Doktora derecesini de Dumlupınar Üniversitesi'nden İşletme dalından aldı (2008). Dumlupınar Üniversitesi'nde çalışmaya başladı (2000). Halen Dumlupınar Üniversitesi Kütahya Sosyal Bilimler Meslek Yüksekokulu'nda görev yapmaktadır. Temel çalışma alanları Yönetim Psikolojisi ve Örgütsel Davranış'dır.

\section{Ömer Zafer GÜVEN}

Uludağ Üniversitesi Balıkesir Turizm İşletmeciliği ve Otelcilik Yüksekokulundan mezun oldu (1991). Yüksek Lisans derecesini Balıkesir Üniversitesi'nden Turizm İşletmeciliği dalından (2002), Doktora derecesini de Dumlupınar Üniversitesi'nden İșletme dalından aldı (2007). Dumlupınar Üniversitesi'nde çalışmaya başladı (1997). Halen Dumlupınar Üniversitesi Kütahya Sosyal Bilimler Meslek Yüksekokulu'nda görev yapmaktadır. Temel çalışma alanları Turizm Pazarlama, Yönetim ve Sağlık Turizmi'dir. 